eISSN: $2655-8688$

http://jurnal.stikes-sitihajar.ac.id/index.php/jhsp hal: $91-99$
pISSN: 2548-3943

received Mei, Accepted Mei, Publish Juni

Volume 1, Nomor 2 - 2019

Copyright @2019. This is an open-access arcle distributed under the terms of the CreaveCommons A

nc-sa/4.0/which permits unrestricted non-commercial used, distribuon and reproducon in any medium

\title{
Faktor yang Berhubungan dengan Perilaku Safety Riding Pengemudi Ojek Online (GoJek) di Kota Medan Sumatera Utara
}

\author{
Jasmen Manurung ${ }^{1}$, Mido Ester Sitorus ${ }^{1}$, Rinaldi ${ }^{1}$ \\ ${ }^{1}$ Universitas Sari Mutiara Indonesia Gedung B Lantai 1 J1. Kapten Muslim No. 79 Medan \\ 20123, Indonesia \\ Email: jasmenmanurung79@yahoo.com
}

\begin{abstract}
ABSTRAK
Adanya aplikasi Go-Jek berbasis online ini menyebabkan penumpukan kendaraan di jalanan, sehingga faktor resiko kecelakaan semakin tinggi. Penelitian ini bertujuan untuk mengetahui faktor-faktor yang berhubungan dengan perilaku safety riding pengendara Go-Jek di Kota Medan. Penelitian ini merupakan penelitian kuantitatif dengan desain cross sectional. Sampel penelitian adalah pengendara Go-Jek di Kota Medan sebanyak 100 responden yang di ambil secara accidental sampling. Hasil penelitian menunjukkan bahwa faktor yang berhubungan dengan faktor perilaku safety riding adalah usia $(p$-value $=0,000)$, masa berkendara ( $p$-value $=$ $0,000)$, kondisi kendaraan ( $p$-value $=0,000)$, kelengkapan berkendara ( $p$-value $=0,000)$. Adapun variable yang tidak berhubungan yaitu pengetahuan $(p$-value $=0,420)$, dari hasil yang didapatkan diharapkan adanya peran berbagai pihak, baik pemerintah, kepolisian, institusi pendidikan, serta perusahaan untuk membuat program pelatihan keselamatan berkendara yang aman, serta lebih mensosialisasikan penggunaan perlengkapan sepeda motor. Selain itu, pengendara Go-Jek diharapkan untuk selalu mematuhi tata cara ketentuan berlalu lintas.
\end{abstract}

Kata Kunci : Perilaku, Safety Riding, Go-Jek

\section{Factors Associated with Behavioral Safety Riding Online Motorcycle driver (GoJek) in the city of Medan, North Sumatra}

\begin{abstract}
With this online-based motorcycle taxi application, it causes a buildup of vehicles on the road, so the risk factor for accidents is higher. Riders or often called Go-Jek partners in the city of Medan have reached 1,479 partners. Partners go to a motorcycle that uses two wheels (GoBike) as many as 964 partners. Therefore, this study aims to find out the factors related to the safety riding behavior of Go-Jek riders in the city of Medan. This research is a quantitative study with cross sectional design. The research sample was all of the Go-Jek riders in Medan city as many as 100 respondents who were taken by incidental sampling. Data analysis consisted of univariate and bivariate analysis using Chi Square statistical tests. The results showed that the factors related to safety riding behavior factors were age ( $p$ Value $=0,000$ ), driving period $(p$ Value $=0.000)$, vehicle condition $(p$ Value $=0,000)$, completeness of driving $(p$ Value $=0,000)$. The unrelated variables are knowledge $(p$ Value $=0.420)$, the results obtained are expected to have the role of various parties, both government, police, educational institutions, and companies to make a safe driving safety training program, as well as more socializing in the use of motorcycle equipment. In addition, Go-Jek drivers are expected to always comply with the procedures for traffic regulations.
\end{abstract}

Keywords: behavior, Safety Riding, Go-Jek 


\section{Pendahuluan}

Kecelakaan lalu lintas masih menjadi masalah global sampai dengan saat ini. Berdasarkan Undang-Undang Nomor 22 Tahun 2009 tentang Lalu Lintas dan Angkutan Jalan, kecelakaan lalu lintas diartikan sebagai suatu peristiwa di jalan yang tidak diduga dan tidak disengaja yang melibatkan kendaraan dengan atau tanpa pengguna jalan lain yang dapat mengakibatkan korban manusia dan/atau kerugian harta benda. Dampak akibat kecelakaan lalu lintas yang mengakibatkan korban manusia dapat berupa luka ringan, luka berat bahkan hingga kematian (Korlantas POLRI, 2014)

Adapun dampak kerugian material yang ditimbulkan akibat kecelakaan lalu lintas secara global telah mencapai US $\$ 518$ milyar tiap tahunnya dimana sekitar US\$65 milyar berasal dari negara-negara dengan berpendapatan menengah dan rendah (WHO, 2014). WHO dalam Global Status Report on Road Safety (2015) melaporkan bahwa proporsi kematian akibat kecelakaan sepeda motor tertinggi terjadi di negaranegara Asia Tenggara dan negara-negara Asia Pasifik dimana masing-masing sebesar 34\% (WHO, 2015). Indonesia sendiri masuk dalam kategori 10 besar negara dengan kasus kecelakaan lalu lintas terbanyak, yakni urutan keenam dari 185 negara (WHO, 2013). Di Indonesia, kecelakaan lalu lintas sepeda motor pada tahun 2013 menempati urutan tertinggi yakni sebesar 119.560 kejadian (Dirjen Perhubungan Darat, 2014).

Menurut data statistik yang dibuat oleh Korlantas Polri pada tahun 2017 menyebutkan bahwa terdapat 39.369 kejadian kecelakaan di Indonesia sepanjang tahun 2017, dimana jumlah itu adalah jumlah keseluruhan dari korban kecelakaan luka ringan, luka berat dan korban meninggal dunia. Di Sumatera Utara Sendiri terdapat 2.488 kejadian kecelakaan yang di antaranya terdapat 489 korban meninggal dunia, 414 korban luka berat, dan 1.585 korban luka ringan (https://databoks.katadata.co.id)
Seiring dengan berkembangnya teknologi saat ini terdapat aplikasi yang mengenalkan layanan pemesanan ojek menggunakan teknologi yang dibantu dengan adanya layanan internet. Penyedia jasa ojek online tersebut dikenal dengan nama Go-Jek, Uber, Blu-Jek. Semua memberikan pelayanan yang hampir sama mulai dari mengantarkan orang dengan biaya yang berbeda-beda, namun dengan sistem pemesanan yang sama yaitu pemesanan melalui aplikasi telepon genggam. Salah satu aplikasi ojek online yang terbesar dan paling banyak dipakai adalah Go-Jek yang hampir dapat di jumpai disetiap mulut-mulut jalan di Kota Medan (Anjani S., 2017).

Go-Jek menjadi pionir layanan ojek berbasis aplikasi mobile melalui layanan Go-Ride-nya. Dengan ini, pengguna aplikasi Go-Jek cukup memesan ojek melalui aplikasi mobile secara online dan nantinya akan dijemput oleh driver ojek yang merespon pesanan pengguna atau calon penumpang. Transaksi pembayaran dilakukan saat pengguna sampai ke tujuan kepada supir ojek. Tarif yang dikenakan bervariasi berdasarkan jarak yang ditempuh atau berdasarkan flat rate yang diberlakukan. Beberapa perusahaan yang menjadi pesaing Go-Jek adalah GrabTaxi, dengan GrabBike-nya, dan Blu-Jek. Kedua perusahaan ini memiliki layanan yang serupa dengan layanan Go-Ride dari GoJek (Agustin, A., 2017).

Data yang di dapatkan dari Korlantas Polri bahwa pada tahun 2017 telah terjadi 103 kejadian kecelakaan yang di alami oleh driver Go-Jek. Faktor-faktor yang menyebabkan tindakan tidak aman ada 2 faktor yaitu faktor manusia dan faktor lingkungan (Geller, 2001). Beberapa penelitian menujukkan faktor-faktor yang banyak menimbulkan kecelakaan yaitu berasal dari faktor perilaku bekerja yang tidak aman (unsafe Action).

Hasil penelitian di Semarang pada tahun 2013 pada mahasiswa Kesehatan Masyarakat Universitas Dian Nuswantoro didapatkan hasil ada hubungan yang 
bermakna antara pengetahuan keselamatan dan kesehatan berkendara dengan praktik keselamatan dan kesehatan berkendara pada pengendara sepeda motor (Perwitaningsih, 2013). Seperti yang dijelaskan oleh Korlantas 2017 yang menyebutkan bahwa faktor yang menjadi penyebab kecelakaan dapat terbagi menjadi 4, yaitu faktor manusia, faktor kendaraan, faktor jalan, dan faktor lingkungan dimana faktor manusia merupakan penyumbang tertinggi terjadinya kecelakaan lalu lintas.

Kota Medan merupakan wilayah dengan lalu lintas kendaraan yang cenderung padat setiap harinya. Karena merupakan Ibu Kota Provinsi terbesar ketiga di Indonesia setelah Jakarta dan Surabaya. Pengendara Go-Jek di kota medan bekerja dari puku 06.00 sampai pukul 19.00 dengan jam kerja dan jam istrahat yang tidak tentu. Kadang juga sampai jam 23.30 untuk mencapai target orderan setiap hari. Berdasarkan survey awal yang dilakukan oleh peneliti dengan wawancara kepada 10 driver Go-Jek di dapat hasil sebagai berikut: sebanyak $80 \%$ pengedara memakai sepatu. $100 \%$ pengendara memakai jacket. $100 \%$ menyediakan helm standart bagi penumpang, $100 \%$ pengendara memakai helm standar dan $80 \%$ pengendara memakai kaca spion standard. Selain itu berdasarkan hasil observasi peneliti di dapati bahwa pengendara menaati peraturan peraturan rambu lalu lintas, menikung dengan menyalakan lampu sein kana maupun kiri, kadang memakai hp saat berkendara serta kurang berkonsentrasi dalam berkendara. Berdasarkan hal tersebut, maka perlu dilakukan penelitian untuk menganalisis hubungan antara umur, pengetahuan, lama berkendara, kelengkapan berkendara dan kelengkapan berkendara dengan perilaku safety riding pada pengendara Go-Jek sepeda motor di Kota Medan Sumatera Utara.

\section{Metode Penelitian}

Jenis penelitian ini adalah penelitian analitik dengan desain cross sectional dimana populasinya adalah pengendara GoJek yang ada di kota Medan yang berjumlah 100 orang. Teknik pengambilan sampel dilakukan dengan metode accidental sampling. Penelitian dilakukan dari bulan Januari - Mei 2018. Pengumpulan data dilakukan melalui bantuan kuesioner yang telah diuji validitas dan reliabilitasnya sebelumnya. Analisis statistik dilakukan dengan menggunakan uji chi square dengan $\mathrm{CL}=95 \%$ dan $\alpha=0,05$.

\section{Hasil}

\section{Distribusi Responden}

Tabel 1 Distribusi Frekuensi Responden

\begin{tabular}{llcc}
\hline \multicolumn{1}{c}{ Variabel } & \multicolumn{1}{c}{ Kategori } & Jumlah (N) & Presentase \% \\
\hline Pengetahuan & Kurang & 45 & $45 \%$ \\
& Baik & 55 & $55 \%$ \\
\hline Usia & Muda & 34 & $34 \%$ \\
& Tua & 66 & $66 \%$ \\
\hline Masa Berkendara & Baru & 30 & $30 \%$ \\
& Lama & 70 & $70 \%$ \\
\hline Kondisi Kendaraan & Lengkap & 72 & $72 \%$ \\
& Tidak Lengkap & 28 & $28 \%$ \\
\hline Kelengkapan Berkendara & Lengkap & 87 & $87 \%$ \\
& Tidak Lengkap & 13 & $13 \%$ \\
\hline Perilaku Berkendara & Safety & 63 & $63 \%$ \\
& Unsafety & 37 & $63 \%$ \\
\hline
\end{tabular}


Berdasarkan Tabel 1 distribusi frekuensi pengetahuan pengendara tentang perilaku berkedara yang benar pada kategori baik sebanyak 55\%. Sebagian besar pengendara berumur lebih dari 30 tahun $(66 \%)$, usia termuda adalah 20 tahun, dan usia yang terua adalah 54 tahun. Ratarata umur pengendara adalah 32,5 tahun.
Sebagian besar memiliki masa berkendara di atas 6 tahun sebanyak 70\%. Rata-rata masa berkendara pengendara Go-Jek adalah 12.5 tahun. Sebanyak $72 \%$ pengendara memliki kondisi kendaraan yang lengkap, 87 pengendara memliki perlengkaan yang lengkap dan $63 \%$ telah berperilaku safety riding.

\section{Hubungan Pengetahuan dengan Perilaku Safety Riding}

Tabel 2 Hubungan Pengetahuan dengan Perilaku Safety riding

\begin{tabular}{|c|c|c|c|c|c|c|c|}
\hline \multirow{3}{*}{ Pengetahuan } & \multicolumn{6}{|c|}{ Perilaku Safety riding } & \multirow{3}{*}{$p$-value } \\
\hline & \multicolumn{2}{|c|}{ Safety } & \multicolumn{2}{|c|}{ Unsafety } & \multicolumn{2}{|c|}{ Total } & \\
\hline & $\mathrm{F}$ & $\%$ & $\mathrm{~F}$ & $\%$ & $\mathrm{~F}$ & $\%$ & \\
\hline Baik & 16 & 16,0 & 23 & 23,0 & 39 & 39,0 & \multirow{2}{*}{0,420} \\
\hline Kurang & 22 & 22,0 & 39 & 39,0 & 61 & 61,0 & \\
\hline & 38 & 38 & 62 & 62 & 100 & 100 & \\
\hline
\end{tabular}

Berdasarakan tabel 2 diatas menujukkan bahwa ada $23,0 \%$ pengendara yang memiliki pengetahuan yang baik tentang perilaku safety riding namun perilaku berkendaraannya tetap tidak aman. Hal ini menunjukkan bahwa pengetahuan tentang perilaku safety riding masih terbatas dalam bentuk pengetahuan, belum

Hubungan Usia dengan Perilaku Safety Riding

Tabel 3 Hubungan Usia dengan Perilaku Safety Riding

\begin{tabular}{|c|c|c|c|c|c|c|c|}
\hline \multirow{3}{*}{ Usia } & \multicolumn{6}{|c|}{ Perilaku Safety riding } & \multirow{3}{*}{$p$-value } \\
\hline & \multicolumn{2}{|c|}{ Safety } & \multicolumn{2}{|c|}{ Unsafety } & \multicolumn{2}{|c|}{ Total } & \\
\hline & $\mathrm{F}$ & $\%$ & $\mathrm{~F}$ & $\%$ & $\mathrm{~F}$ & $\%$ & \\
\hline Muda & 0 & 0 & 34 & 34 & 34 & 34 & 0000 \\
\hline Tua & 37 & 37 & 29 & 29 & 66 & 66 & 0,000 \\
\hline & 37 & 37 & 63 & 63 & 100 & 100 & \\
\hline
\end{tabular}

Tabel 3 menujukkan bahwa tidak ada pengendara berusia muda yang memiliki perilaku safety riding, namun pada usia tua perilaku safety riding tertinggi pada kategori safety. Hasil uji statistik juga

diaplikasikan pengendara dalam berkendara sehari-hari. Hasil uji statistik di dapatkan $p$ value $0,420(p>0,05)$ maka dapat disimpulkan bahwa tidak ada hubungan signifikan antara pengetahuan dengan perilaku safety riding pada pengendara GoJek.

\section{Hubungan Masa Berkendara dengan Perilaku Safety Riding}

Tabel 4. Hubungan Masa Berkendara dengan Perilaku Safety Riding

\begin{tabular}{|c|c|c|c|c|c|c|c|}
\hline \multirow{3}{*}{$\begin{array}{c}\text { Masa } \\
\text { Berkendara }\end{array}$} & \multicolumn{6}{|c|}{ Perilaku Safety Riding } & \multirow{3}{*}{ p-value } \\
\hline & \multicolumn{2}{|c|}{ Safety } & \multicolumn{2}{|c|}{ Unsafety } & \multicolumn{2}{|c|}{ Total } & \\
\hline & $\mathrm{F}$ & $\%$ & $\mathrm{~F}$ & $\%$ & $\mathrm{~F}$ & $\%$ & \\
\hline Baru & 8 & 8,0 & 22 & 22,0 & 30 & 30,0 & 0000 \\
\hline Lama & 54 & 54,0 & 16 & 16,0 & 70 & 70,0 & 0,000 \\
\hline
\end{tabular}




\begin{tabular}{llllll}
\hline 62 & 62,0 & 38 & 38,0 & 100 & 100,0 \\
\hline
\end{tabular}

Tabel 4 menujukkan bahwa sebagian besar pengendara baru memiliki perilaku safety riding kategori unsafety, namun pada responden yang masa berkendaraan lama menunjukkan sebagian besar memiliki perilaku berkendaraan yang

Hubungan Kondisi Kendaraan Perilaku Safety Riding

Tabel 5 Hubungan Kondisi Kendaraan dengan Perilaku Safety riding

\begin{tabular}{|c|c|c|c|c|c|c|c|}
\hline \multirow{3}{*}{$\begin{array}{c}\text { Kondisi } \\
\text { Kendaraan }\end{array}$} & \multicolumn{6}{|c|}{ Perilaku Safety riding } & \multirow{3}{*}{ p-value } \\
\hline & \multicolumn{2}{|c|}{ Safety } & \multicolumn{2}{|c|}{ Unsafety } & \multicolumn{2}{|c|}{ Total } & \\
\hline & $\mathrm{F}$ & $\%$ & $\mathrm{~F}$ & $\%$ & $\mathrm{~F}$ & $\%$ & \\
\hline Kurang & 6 & 6,0 & 22 & 22,0 & 28 & 28,0 & \multirow{2}{*}{0,000} \\
\hline Lengkap & 56 & 56,0 & 16 & 16,0 & 72 & 72,0 & \\
\hline & 38 & 38,0 & 62 & 62,0 & 100 & 100,0 & \\
\hline
\end{tabular}

Berdasarkan Tabel 5 diatas menujukkan bahwa pengendara dengan kondisi kendaraan yang kurag lengkap cenderung memiliki perilaku berkendaraan yang unsafe. Kondisi kendaraan yang dimaksud adalah alat kendali, ban, lampu safety. Hasil uji statistik juga menunjukkan bahwa $p$-value $0,000(p<0,05)$ maka dapat disimpulkan bahwa ada hubungan antara masa berkendara dengan perilaku safety riding pada pengendara Go-Jek.

\begin{abstract}
dan sein, spion, oli dan rantai. Hasil uji statistik Chi Square di dapatkan $p$-value $0,000(\mathrm{p}<0,05)$ maka dapat disimpulkan bahwa ada hubungan antara kondisi kendaraan dengan perilaku safety riding pada pengendara Go-Jek.
\end{abstract}

Hubungan Kelengkapan Berkendara dengan Perilaku Safety Riding

Tabel 6 Hubungan Kelengkapan Berkendara dengan Perilaku Safety riding

\begin{tabular}{ccccccccc}
\hline \multirow{2}{*}{$\begin{array}{c}\text { Kelengkapan } \\
\text { Berkendara }\end{array}$} & \multicolumn{6}{c}{ Safety } & \multicolumn{3}{c}{ Unsafety } & \multicolumn{2}{c}{ Total } & \multirow{2}{*}{$\boldsymbol{p}$-value } \\
\cline { 2 - 7 } & \multicolumn{2}{c}{ F } & $\%$ & $\mathrm{~F}$ & $\%$ & $\mathrm{~F}$ & $\%$ & \\
\hline Kurang & 0 & 0,0 & 13 & 13,0 & 13 & 13,0 & \multirow{2}{*}{0,000} \\
Lengkap & 62 & 62,0 & 25 & 25,0 & 87 & 87,0 & \\
\hline & 62 & 62,0 & 62 & 38,0 & 100 & 100,0 & \\
\hline
\end{tabular}

Pada Tabel 6 dapat dilihat bahwa tidak ada pengendara yang memiliki kelengkapan berkendara yang berperilaku safety dalam berkendaraan. Sebanyak $62 \%$ pengendara yang memiliki kelengkapan berkendara yang lengkap memiliki perilaku

\section{Pembahasan}

\section{Hubungan Pengetahuan dengan Perilaku Safety Riding}

Pengetahuan adalah hasil penginderaan manusia, atau hasil ingin tahu seseorang terhadap objek, melalui indera yang dimilikinya (mata, hidung, telinga dan sebagainya). Dengan sendirinya, pada yang safety dalam berkendara. Hasil uji statistik juga menunjukkan p-value 0,00 $(\mathrm{p}<0,05)$. Hal ini membuktikan bahwa ada hubungan antara kelengkapan berkendara dengan perilaku safety riding pada pengendara Go-Jek.

waktu penginderaan sampai menghasilkan pengetahuan tersebut sangat dipengaruhi oleh intensitas perhatian dan persepsi terhadap objek. Pengetahuan atau kognitif merupakan domain yang sangat penting untuk terbentuknya tindakan seseorang (overt behavior). Dari pengalaman dan penelitian ternyata perilaku yang 
didasarkan oleh pengetahuan akan lebih langgeng dari pada perilaku yang tidak didasari oleh pengetahuan (Notoatmodjo, 2012).

Safety riding adalah suatu usaha yang dilakukan dalam meminimalisir tingkat bahaya dan memaksimalkan keamanan dalam berkendara, demi menciptakan suatu kondisi aman, yang mana kita berada pada titik tidak membahayakan pengendara lain dan menyadari kemungkinan bahaya yang dapat terjadi di sekitar kita serta pemahaman akan pencegahan dan penanggulangannya (Berlianto, 2007).

Hasil penelitian hasil penelitian menunjukkan tidak ada hubungan yang signifikan antara pengetahuan dengan safety riding ( $p$-value 0,420$)$. Hasil penelitian ini sejalan dengan penelitian Ariwibowo (2013), tentang hubungan antara umur, tingkat pendidikan, pengetahuan, sikap terhadap praktik safety riding awareness pada pengendara ojek sepeda motor. Penelitian tersebut menunjukan bahwa tidak adanya hubungan antara perilaku dengan safety riding pada pengendara ojek sepeda motor $(\mathrm{p}$-value $=$ 0,514). Pengetahuan memang merupakan domain yang sangat penting dalam membentuk tindakan seseorang, namun tidak selalu berpengaruh terhadap tindakan seseorang. Seseorang dokter sangat mengetahui akibat kesehatan dari tindakan merokok, namun tetap merokok. Hal ini disebabkan oleh masih adanya komponen lain yang juga berpengaruh terhadap pembentukan tindakan seseorang, seperti: umur, pendidikan, pengalaman, dan berbagai faktor lainnya (Notoatmodjo, S., 2012).

\section{Hubungan Usia dengan Perilaku Safety Riding}

Usia merupakan salah satu faktor yang dapat mempengaruhi seseorang dalam melakukan aktivitas kesehariannya. Umur mempunyai pengaruh yang besar terhadap kejadian kecelakaan lalu lintas. Umur 30 tahun atau lebih akan mengendarai secara hati-hati sedangkan sebaliknya mereka mengendarai secara tidak hati-hati dan membayakan pengendara lain (Nawangwulan,1998). World Health Organization (WHO) Tahun 2011 menyatakan sebanyak $67 \%$ korban kecelakaan lalu lintas berada pada umur produktif yakni 22-50 tahun, pernyataan lainnya menyatakan bahwa kecelakaan lalu lintas adalah penyebab utama kematian anak-anak di dunia, dengan rentang umur 10-24 tahun (Badan Inteligen Negara. 2014).

Hasil penelitian ini menunjukkan bahwa ada hubungan yang antara umur dengan safety riding pada pengendara ojek. Penelitian ini sejalan dengan hasil penelitian sebelumnya yang dilakukan oleh Rukhfiati pada tahun 2010 yang menyatakan jika pengendara yang berumur di atas 30 tahun lebih matang dan lebih pengalaman dalam berperilaku mengendarai sepeda motor, daripada pengendara yang berumur di bawah 30 tahun. Hal tersebut dikarenakan umur merupakan salah satu faktor yang berhubungan dengan perilaku seseorang. Seseorang yang memiliki umur yang matang akan berperilaku aman berkendara. Untuk itu, perlu penegakan peraturan terhadap para pengendara yang masih berumur di bawah 17 tahun sesuai dengan Undang-Undang No. 22 Tahun 2009 tentang Lalu Lintas dan Angkutan Jalan.

\section{Hubungan Masa Berkendara dengan Perilaku Safety Riding}

Pengalaman berasal dari kata dasar "alami" yang artinya mengalami, melakoni, menempuh, menemui, mengarungi, mendapat, menyelami, dan merasakan (Endarmoko, 2006). Pengalaman merupakan guru yang baik, yang bisa menjadi sumber pengetahuan dan juga merupakan suatu cara untuk memperoleh kebenaran pengetahuan (Sugiyono, 2010). Pengalaman dapat diartikan juga sebagai memori masa, yaitu memori yang menerima dan menyimpan peristiwa- 
peristiwa yang telah terjadi atau dialami individu pada waktu dan tempat tertentu, berfungsi sebagai referensi otobiografi (Syah, 2003).

Masa berkendara dihitung dari pertama kali pengendara bisa mengendarai sepeda motor sampai dilakukan penelitian ini. Hasil distribusi responden menurut data masa berkendara, pengendara yang berkendara sepeda motor $>6$ tahun sebanyak $70(70 \%)$ dan pengendara yang berkendara dibawah 6 tahun sebanyak 30 pengendara $(30 \%)$. Hasil penelitian menunjukkan bahwá ditemukannya hubungan antara masa berkendara dengan safety riding ( $p$ value- 0,000 ).

Adanya hubungan pada variable ini dikarenakan ketika seseorang mempunyai masa berkendara yang lama akan lebih cenderung melakukan tindakan yang aman pada saat berkendara, karena sudah terbiasa dengan mengendarai secara aman dan faktor lain seperti lingkungan yang mengakibatkan perilaku pengendara aman. Hasil penelitian ini sesuai dengan pernyataan yang ada, bahwa masa berkendara seseorang dapat mempengaruhi perilaku seseorang dalam berkendara yang aman, seharusnya jika pengendara pengalaman berkendaranya sudah lama maka akan mengendarai sepeda motor secara aman dan sebaliknya jika pengendara yang baru memiliki pengalaman berkendara maka akan melakukan perilaku berkendara secara tidak aman.

\section{Hubungan Kondisi Kendaraan dengan Perilaku Safety Riding}

Sepeda motor memiliki standarstandar kelengkapan yang wajib memenuhi persyaratan teknis. Pemeriksaan persyaratan teknis pada kendaraan sepeda motor berfungsi untuk menghindari ancaman yang datang tiba-tiba saat mengendarai sepeda motor di jalan raya. Berdasarkan hasil penelitian diketahui bahwa responden yang komponen pendukung sepeda motornya lengkap lebih banyak jumlahnya (72\%) dibanding responden yang komponen pendukung sepeda motornya tidak lengkap (28\%). Kebanyakan dari responden memiliki sepeda motor dengan produksi terbaru sehingga komponen sepeda motornya masih terbilang lengkap, seperti adanya kaca spion, berfungsinya spidometer, lampu sein, lampu utama lampu rem dan spakebor pada sepedamotor.

Pada analisa tabel silang menunjukan bahwa lebih banyak responden yang tidak lengkap memiliki komponen pendukung pada sepeda motornya dan berperilaku kurang baik dalam berkendara sepeda motor (22\%). Berdasarkan hasil uji statistik diketahui bahwa terdapat hubungan yang bermakna antara kelengkapan komponen sepeda motor dengan perilaku berkendara sepeda motor. Komponen kondisi kendaraan pada sepeda motor menjadi penting karena masing- masing darinya memiliki fungsi yang berbeda-beda yang dapat mengurangi risiko terjadinya kecelakaan.

Oleh karena itu diharapkan Dinas Perhubungan Darat bekerjasama dengan kepolisian saat melakukan operasi razia untuk melakukan pemeriksaan secara menyeluruh terhadap perlengkapan komponen pendukung yang terdapat pada kendaraan agar pengendara sadar akan pentingnya kelengkapan komponen pendukung tersebut pada kendaraan khususnya sepeda motor.

\section{Hubungan Kelengkapan Berkendara dengan Perilaku Safety Riding}

Ketersediaan perlengkapan keselamatan berkendara dalam penelitian ini adalah helm berdasarkan standar nasional Indonesia, alat pelindung wajah dan mata, sarung tangan, jaket/rompi, celana panjang dan sepatu yang menutupi tumit. Dikatakan lengkap apabila responden lengkap (100\%) memiliki perlengkapan keselamatan berkendara dan dikatakan tidak lengkap $(<100 \%)$ apabila tidak memiliki satu atau lebih perlengkapan keselamatan berkendara.

Berdasarkan hasil penelian diketahui bahwa responden yang 
perlengkapan keselamatan berkendara sepeda motornya termasuk dalam kategori tidak lengkap lebih sedikit jumlahnya $(13 \%)$ dibanding responden yang perlengkapan keselamatan berkendara sepeda motornya lengkap (87\%). Pada penelitian ini, perlengkapan keselamatan yang paling jarang ditemukan di responden adalah sarung tangan. Analisa tabel silang menunjukan bahwa lebih banyak responden yang tidak lengkap memiliki perlengkapan keselamatan berkendara sepeda motor berperilaku kurang baik dalam berkendara sepeda motor yaitu sebesar $57.7 \%$. Responden yang tidak memiliki ataupun tidak membawa perlengkapan keselamatan, berarti sama saja tidak memakainya.

Hasil tersebut di dukung dengan uji statistik yang menunjukkan bahwa terdapat hubungan yang bermakna antara ketersediaan perlengkapan keselamatan pengendara sepeda motor dengan perilaku berkendara sepeda motor. Hal ini sejalan dengan penelitian Melisa, A. (2013), yang menyatakan bahwa terdapat hubungan antara Alat Pelindung Diri (APD) dengan perilaku berkendara aman (safety riding) dan hal ini juga membuktikan pernyataan Green (2005), bahwa ketersediaan sarana merupakan salah satu faktor pemungkin yang memfasilitasi motivasi untuk dapat diwujudkan menjadi kenyataan. Dengan kata lain Faktor predisposisi (pengetahuan, sikap, dsb) belum cukup membuat seseorang berperilaku, perlu fasilitas untuk mendukung terjadnya perilaku tersebut.

\section{Kesimpulan}

Tidak ada hubungan antara pengetahuan dengan perilaku safety riding pada pengendara Go-Jek. Ada hubungan antara usia dengan perilaku safety riding pada pengendara Go-Jek. Ada hubungan masa berkendara dengan perilaku safety riding pada pengendara Go-Jek. Ada hubungan antara kondisi kendaraan dengan perilaku safety riding pada pengendara GoJek. Ada hubungan antara perlengkapan berkendara dengan perilaku safety riding pada pengendara Go-Jek.

\section{Referensi}

Agustin, A. 2017. Persepsi Masyarakat Tehadap Penggunaan Transportasi Online (GO-JEK) di Surabaya. Jurnal Ilmu dan Rist Manajemen. Volume. 6. Nomor. 9

Anjani, S. 2017 Transportasi Berbasis Aplikasi Online: Go-Jek Sebagai Sarana Transportasi Masyarakat Kota Surabaya. Skripsi. Universitas Airlangga.

Ariwibowo. 2013. Hubungan Antara Umur, Tingkat Pendidikan, Pengetahuan, Sikap Terhadap Praktik Safety Riding Awwareness Pada Pengendara Ojek Sepeda Motor di Kecamatan Banyumanik. Junal Kesehatan Masyarakat, volume 2, nomor 1.

Badan Inteligen Negara. 2014. Kecelakaan Lalu Lintas Menjadi Pembunuh Terbesar Ketiga. Diakses pada 10 April 2018 dalam situs web: www.bin.go.id/awas/detil/197

Berlianto, A. 2007. Safety Riding Community. Diakses 1 Mei 2018. http:saft7.com

Dirjen Perhubungan Darat, 2014. Perhubungan Darat Dalam Angka 2013.

Endarmoko, E. 2006. Tesaurus Bahasa Indonesia. Cet. I; Jakarta: PT Gramedia.

Dkatadata.co.id. Sepanjang 2017 Terjadi 98 Ribu Kali Kecelakaan Lalu Lintas. Diakses $12 \quad$ Mei 2018. https://databoks.katadata.co.id.

Geller, E.S. 2001. Working Safe. How to Help People Actively Care for Helath and Safety. Lewis Publisher.

Korlantas POLRI, 2014. Polantas Dalam Angka 2013

Melisa, A. 2013. Analisis Faktor-faktor yang Mempengaruhi Perilaku Berkendara Aman (Safety Riding) pada Pengendara Ojek di Universitas Indonesia Depok Tahun 2012. Skripsi. Fakultas Kesehatan Masyarakat Universitas Indonesia. 
Nawangwulan, D. 1998. Gambaran Kecelakaan Lalu Lintas Kendaraan Di PT. Indocement Tunggal Prakasa Tbk Bogor. Jakarta: Universitas Indonesia.

Notoatmodjo, S. 2012. Promosi Kesehatan dan Perilaku Kesehatan. Jakarta: PT. Rineka Cipta.

Perwitaningsih, R. 2013. Hubungan antara Pengetahuan dan Sikap Terhadap Praktik Keselamatan dan Kesehatan Berkendara Sepeda Motor pada Mahasiswa Kesehatan Masyarakat Udinus Semarang Tahun 2013. Jurnal Udinus.

Rukhfiati, dian. Hubungan Umur, Pengetahuan, Sikap, Dukungan
Keluarga, Dukungan Teman Kerja Dengan Praktik Safety riding pada Karyawan Bisnis Development Representatif (BDR). Semarang: Skripsi Fakultas Kesehatan Masyarakat Universitas Diponegoro. 2010

Sugiyono. 2010. Metode Penelitian Pendidikan Pendekatan Kuantitatif, kualitatif, dan R\&D. Bandung: Alfabeta

Syah, M. 2003. Psikologi Belajar. Jakarta: PT Raja Grafindo.

Undang-Undang No. 22 Tahun 2009 tentang Lalu Lintas dan Angkutan Jalan 